\title{
TERAJU
}

Teraju: Jurnal Syariah dan Hukum

Volume 01 Nomor 02, September 2019

DOI: $10.35961 /$ teraju.v1i02.88

\section{Pembaharuan Hukum Perkawinan Tentang Batas Minimal Usia Pernikahan dan Konsekuensinya}

\author{
Supri Yadin Hasibuan \\ STAIN Sultan Abdurrabman Kepulauan Riau \\ supri_yadin@stainkepri.ac.id \\ Ahmad Jalili \\ STAIN Sultan Abdurrabman Kepulauan Riau \\ abmadjalili@stainkepriac.id
}

\section{Firdaus}

STAIN Sultan Abdurrabman Kepulauan Riau

firdaus@stainkepri.ac.id

\section{Zulfahmi}

UIN Sultan Syarif Kasim Rian

Zulfahmi91@uin-suska.ac.id

\begin{abstract}
Abstrak
Tulisan ini membahas tentang pembaharuan hukum perkawinan tentang batas minimal usia pernikahan dan akibat hukumnya. Masalahny adalah faktor apa saja yang menyebabkan pernikahan di bawah umur dan dampak apa saja dari pernikahan di bawah umur tersebut. Permasalahan ini akan dikaji dengan menggunakan metode penelitian dengan pendekatan kualitatif. Penelitian ini ditemukan bahwa tidak ada pengaturan hukum yang khusus menyangkut perkawinan anak dibawah umur. Anak dibawah umur menurut sistem hukum di Indonesia yaitu Undang-Undang Perkawinan (UUP) di Indonesia adalah anak yang berusia 19 (sembilan belas) tahun untuk pria dan wanita. Walaupun telah ditegaskan mengenai batas usia minimum diperbolehkan menikah oleh Undang-Undang, namun disisi lain diberikan pengecualian untuk itu. Pengecualian itu disebut dengan pemberian dispensasi kawin untuk anak dibawah umur. Anak dibawah umur yang mendapat dispensasi kawin boleh melaksanakan perkawinan walaupun masih dibawah umur. Anak dibawah umur yang mendapat dispensasi kawin setelah melaksanakan perkawinan, dianggap dewasa dan dianggap cakap dalam melakukan suatu perbuatan hukum, atau ia nya tidak berada dibawah pengampuan orangtuanya lagi.
\end{abstract}

Kata kunci: Pembaharuan Hukum, Perkawinan, Batas Usia Minimal. 


\begin{abstract}
This paper discusses renewal of marriage law regarding the minimum age of marriage and the legal consequences. The problem is what factors cause underage marriages and the effects of any underage marriages. This problem will be examined using research methods with a qualitative approach. This study found that there were no specific legal arrangements regarding the marriage of minors. Underage children according to the legal system in Indonesia, namely the Marriage Law (UUP) in Indonesia are children aged 19 (nineteen) years for men and women. Although it has been stated that the minimum age for marriage is permitted by law, on the other hand exceptions are given for this. The exception is called the dispensation of marriage for minors. Minors who get married dispensation may get married even though they are underage. Minors who receive dispensation to marry after marriage, are considered adults and are considered capable of carrying out legal actions, or he is not under the control of his parents anymore.
\end{abstract}

Keywords: Legal Renewal, Marriage, Minimum Age Limit.

\section{Pendahuluan}

Dalam Hukum Positif Indonesia, mengatur tentang perkawinan yang tertuang di dalam UU No.1 Tahun 1974 menyatakan bahwa "Perkawinan adalah ikatan lahir batin antara seorang pria dengan sesorang wanita sebagai suami istri dengan tujuan membentuk keluarga (Rumah Tangga) yang bahagia dan kekal berdasarkan Ketuhanan Yang Maha Esa".

Bagi perkawinan tersebut tentu harus dapat diperbolehkan bagi mereka yang telah memenuhi batasan usia untuk melangsungkan perkawinan seperti awalnya dalam Pasal 7 ayat 1 UU No.1 Tahun 1974 yang tertera bahwa, batasan usia untuk melangsungkan perkawinan itu pria sudah berusia 19 (Sembilan belas) tahun dan wanita sudah mencapai usia 16 (Enam belas) tahun. ${ }^{2}$ Secara eksplisit ketentuan tersebut dijelaskan bahwa setiap perkawinan yang dilakukan oleh calon pengantin prianya yang belum berusia 19 tahun atau wanitanya belum berusia 16

1 Dijelaskan dalam Undang-undang Perkawinan nomor 1 tahun 1974.

${ }^{2}$ Ibid., tahun disebut sebagai "Perkawinan di bawah umur".

Setelah dibahas secara intensif, akhirnya revisi terbatas dalam UU No.1 Tahun 1974 tentang Perkawinan terkait aturan batas usia pernikahan resmi disetujui menjadi Undang-Undang sesuai amanat putusan MK No. 22/PUUXV/2017 tertanggal 13 Desember 2018.

Dalam pembahasan tersebut, akhirnya disepakati batasan usia perempuan dan laki-laki adalah 19 tahun untuk dapat melangsungkan perkawinan secara sah. Seperti tertuang dalam Pasal 7 ayat (1) UU Perkawinan menyebutkan, "Perkawinan hanya diizinkan apabila Pria dan wanita sudah mencapai umur 19 tahun.” Batasan usia untuk melangsungkan perkawinan itu bukan lagi perempuan yang sudah mencapai usia 16 (enam belas) tahun.

Oleh karena itu, bagi perempuan dan laki-laki yang menikah di bawah umur 19 tahun, maka disebut dengan pernikahan dini atau perkawinan di bawah umur. Bagi perkawinan di bawah umur ini yang belum memenuhi batas usia perkawinan, pada hakikatnya disebut 
masih berusia muda (anak-anak) yang ditegaskan dalam Pasal 81 ayat 2 UU No.23 Tahun 2002, "Bahwa anak adalah seseorang yang belum berusia 18 (delapan belas) tahun dikategorikan masih anakanak, juga termasuk anak yang masih dalam kandungan, apabila melangsungkan perkawinan tegas dikatakan adalah perkawinan di bawah umur.

Tetapi perkawinan di bawah umur merupakan peristiwa yang dianggap wajar dalam suatu masyarakat Indonesia, namun perkawinan di bawah umur bisa menjadi isu yang menarik perhatian publik dan berlanjut menjadi kasus hukum. Maka dalam tulisan yang singkat ini akan membahas sedikit berkenaan dengan pernikahan dibawah umur dan polemik yang terjadi didalamnya.

Berdasarkan latarbelakang masalah yang telah diuraikan di atas, maka dapat dirumuskan beberapa pokok masalah, seperti faktor apa saja yang menyebabkan pernikahan di bawah umur? Dan dampak apa saja dari pernikahan di bawah umur tersebut?

Dalam tulisan ini akan sedikit membahas mengenai sisi berbeda ketika seseorang melakukan nikah di bawah umur. Lalu, bagaimana dampaknya bagi siapa yang melakukan nikah di bawah umur, seperti dampak terhadap hukum, dampak biologis, dampak psikologis, dampak sosial dan dampak perulaku seksual menyimpang

Permasalahan ini akan dikaji dengan menggunakan metode penelitian dengan pendekatan kualitatif, yaitu suatu proses penelitian dan pemahaman yang berdasarkan pada metodologi yang menyelidiki suatu fenomena sosial dan masalah manusia. ${ }^{3}$ Tujuan utama penelitian kualitatif adalah untuk

${ }^{3}$ J.W. Creswell, Qualitatif Inquiry and Research Design, (California: Sage Publications, Inc: 1998), hlm. 15 memahami fenomena dengan lebih menitikberatkan pada gambaran yang lengkap tentang fenomena yang dikaji daripada merincinya menjadi variabelvariabel yang saling terkait. Harapannya ialah diperoleh pemahaman yang mendalam tentang fenomena yang dikaji. ${ }^{4}$

\section{Pembahasan}

\section{a. Arti Pernikahan di Bawah Umur}

Pernikahan Bawah Umur diartikan sebagai sebuah pernikahan yang dilakukan oleh mereka yang berusia di bawah usia yang dibolehkan untuk menikah dalam Undang-Undang Perkawinan (UUP) nomor 1 tahun 1974, yaitu minimal 16 tahun untuk perempuan dan 19 tahun untuk laki-laki.

Berkaitan dengan Undang-Undang Perkawinan (UUP) nomor 1 tahun 1974 tersebut, selanjutnya akan dijelaskan pengertian pernikahan bawah umur menurut beberapa pandangan; Pertama, pernikahan di bawah umur menurut undang-undang.

Dalam Undang-undang Nomor 1 tahun 1974 tentang perkawinan pada Bab II pasal 7 disebutkan bahwasanya perkawinan hanya diizinkan jika pihak pria dan wanita sudah mencapai umur sekurang-kurangnya 19 tahun. $^{6} \quad$ Dalam batas usia pernikahan menurut Kompilasi Hukum Islam (KHI) sama dengan Undang-undang Nomor 1 tahun 1974 tentang perkawinan. Dalam KHI pasal 15 ayat 2 menegaskan bahwa untuk melangsungkan perkawinan seorang yang belum mencapai batas usia 21 tahun harus mendapat izin sebagaimana di atur dalam

4 Agus Salim, Teori dan Paradigma Penelitian Sosial: Dari Denæim Guba dan Penerapannya, (Yogyakarta: Tiara Wacana, 2001), hlm. 11

${ }^{5}$ Ibid.,

${ }^{6}$ Lihat Undang-undang Perkawinan (UUP), Bab II, Pasal 7 
pasal 6 ayat 2, 3, 4 dan 5 Undang-undang Perkawinan Nomor 1 tahun 1974.7

Pernikahan di bawah umur tidak dapat diizinkan kecuali pernikahan tersebut meminta izin nikah atau dispensasi nikah oleh pihak Pengadilan Agama untuk bisa disahkan pernikahannya di Kantor Urusan Agama (KUA), dan sebelum mengajukan permohonan izin menikah di Pengadilan Agama terlebih dahulu kedua calon pasangan yang ingin menikah harus mendapat izin dari kedua orang tua.

Dalam Undang-undang Nomor 1 tahun 1974 tentang perkawinan atau lebih kenalnya dengan Undang-undang Perkawinan dan KHI tidak ada aturan hukum yang menjelaskan batasan minimal usia bagi para pelaku nikah di bawah umur, sehingga dalam hal ini hakim memiliki ijtihad atau pertimbangan hukum sendiri untuk bisa memutuskan perkara permohonan nikah di bawah umur, dan hakim memiliki wewenang penuh untuk mengabulkan sebuah permohonan baik mengabulkan maupun menolak sebuah permohonan penetapan nikah di bawah umur tersebut. $^{8}$

Prinsip Undang-undang ini bahwa calon suami istri itu harus siap jiwa raganya untuk dapat melangsungkan perkawinan, agar dapat mewujudkan tujuan perkawinan secara baik tanpa berakhir pada perceraian dan mendapat keturunan yang baik dan sehat. Dari sisi lain, perkawinan juga mempunyai hubungan dengan masalah kependudukan. Terbukti bahwa batas umur yang lebih rendah bagi seorang wanita untuk menikah, mengakibatkan laju kelahiran yang lebih tinggi jika dibandingkan dengan

7 Penjelasan ini dikutip dari Kompilasi Hukum Islam (KHI) pasal 15 ayat 2

8 Abdul Manan, Etika Hakim dalam Penyelenggaraan Peradilan, Jakarta: Kencana, 2007, hlm.136. batas umur seseorang yang menikah pada usia yang lebih matang atau usia yang lebih tinggi.' Sehingga jelaslah bahwa Undangundang memberikan persetujuan dengan syarat harus adanya Dispensasi Nikah.

Kedua, pernikahan di bawah umur menurut agama. Sebagai muslim, suatu kewajiban untuk merujuk sumber utama dari ajaran Islam, yakni Al-Qur'an. Apakah Al-Qur'an mengizinkan atau melarang perkawinan di bawah umur? Perkawinan adalah suatu aqad yang sangat kuat (misaqan ghalizan) untuk menaati perintah Allah swt dan melaksanakannya merupakan suatu ibadah. ${ }^{10}$ Sedangkan tujuannya untuk mewujudkan rumah tangga yang sakinah mawaddah wa rahmah. ${ }^{11}$ Hukumnya dapat berubah sesuai berubahnya "illah", yaitu dapat sunnah, makruh, haram dan wajib.

Sebagaimana terlihat dalam Hadist berikut " ...... sedangkan aku menikah, maka barangsiapa tidak suka sunnah (petunjukku), maka bukan dari golonganku". Perintah dan anjuran melakukan pernikahan, tidak memberikan batasan umur, namun ditekankan perlunya kedewasaan seseorang melakukan pernikahan untuk mencegah kemudharatan (hal-hal buruk). Sehingga kedewasaan secara psikologis dan biologis secara implicit di anjurkan melalui beberapa Hadist dan yang tertera dalam ayat Al-Qur'an.

Walaupun tidak ada batas usia nikah bagi calon suami, sama hal terhadap batas usia bagi calon istri juga tidak ada ketentuannya. Namun ada sumber hukum

${ }^{9} \mathrm{~K}$. Wancik Saleh, Hukum Perkawinan di Indonesia, Jakarta: Ghalia Indonesia, 1976, hlm.30.

10 Pengertian perkawinan berdasarkan Pasal 2 Kompilasi Hukum Islam (KHI), buku 1 tentang Hukum Perkawinan

11 Khoiruddin Nasution, Hukum perkawinan I, Yogyakarta: ACAdeMIA \& TAZZAFA, 2005, hlm.38-39 
yang diambil dari Aisyah r.a, yang artinya sebagai berikut yang diriwayatkan oleh Imam Bukhari dan Muslim : "Dari Aisyah r.a sesunggubnya Nabi SAW telah menikah dengannya pada saat ia berumur 6 tahun dan ia diserabkan kepada Nabi SAW pada usia 9 tabun". ${ }^{12}$

Hadis di atas hanyalah bersifat khabariyah (kabar) saja tentang perkawinan Nabi Muhammad SAW, namun di dalamnya tidak dijumpai pernyataan baik berupa pernyataan yang mesti diikuti ataupun pernyataan untuk ditinggalkan. Karena itu pernyataan usia yang ada dalam hadis di atas tidak dapat disimpulkan sebagai pernyataan batas usia terendah kebolehan melangsungkan pernikahan bagi kaum wanita.

Namun, muncul kontroversi menyangkut batasan kedewasaan seseorang untuk boleh menikah, yang berimplikasi terhadap tidak ada keberatan atas pernikahan di bawah umur dari pandangan Islam.

Ketiga, pernikahan di bawah umur menurut hukum adat. Hukum adat tidak menentukan batasan umur tertentu bagi orang untuk melaksanakan perkawinan. Bahkan hukum adat membolehkan perkawinan anak-anak yang dilaksanakan ketika anak masih berusia kanak-kanak. Hal ini dapat terjadi karena di dalam Hukum Adat perkawinan bukan saja merupakan persatuan kedua belah mempelai tetapi juga merupakan persatuan dua buah keluarga kerabat. Adanya perkawinan di bawah umur atau perkawinan kanan-kanak tidak menjadi masalah di dalam Hukum Adat karena kedua suami isteri itu akan tetap dibimbing oleh keluarganya, yang dalam hal ini telah menjadi dua keluarga, sehingga Hukum Adat tidak melarang perkawinan kanak-kanak.

${ }^{12}$ Hadis ini dikutip dari Kutub al-Sittab: Kumpulan Hadis-hadis saheh Bukhari-Muslim

\section{b. Faktor Penyebab Pernikahan di Bawah Umur}

Pada umumnya, faktor terjadinya nikah di bawah umur adalah faktor agama, budaya (adat), sosial dan hukum yang berkembang dalam masyarakat, yang diuraikan sebagai berikut :

Pertama, Norma Agama. Dalam hal ini agama tidak mengharamkan atau menentang pernikahan di bawah umur dan tidak ada kriminalisasi terhadap pernikahan di bawah umur, bahkan dalam pandangan Islam "Nikah" adalah fitrah manusia dan sangat dianjurkan bagi umat Islam, karena menikah merupakan naluri kemanusiaan yang harus dipenuhi dengan jalan yang sah agar tidak mencari jalan yang sesat atau jalan yang menjerumuskan dalam hubungan zina. Dan pernikahan usia muda merupakan suatu antisipasi dari orang tua untuk mencegah akibat-akibat negatif yang dapat mencemarkan nama baik dan merusak martabat orang tua dan keluarga. ${ }^{13}$

Perintah dan anjuran melakukan pernikahan, tidak memberikan batasan umur seseorang untuk melakukannya. Namun ditekankan perlunya kedewasaan seseorang melakukan pernikahan untuk mencegah kemudharatan atau hal-hal buruk. Hal ini sangat relevan dengan hukum positif di Indonesia dan Undangundang lainnya yang saling berkaitan perihal pernikahan di bawah umur, bahwasanya tidak ada aturan hukum yang menegaskan dengan berupa memberikan sanksi hukum terhadap para pelaku atau orang-orang yang terkait dalam pernikahan di bawah umur.

Walaupun dalam pasal keluarga untuk mencegah terjadinya perkawinan pada usia anak-anak, namun pernikahan di bawah umur tidak serta merta dipandang

13 Mudzakaroh Al-Azhar, Tentang Perkawinan di Bawah Umur, Jakarta: Prima Cendikia, 1985, hlm.62. 
sebagai tindakan kriminal menurut hukum. Undang-undang perkawinan yang memberikan dispensasi kepada kedua pasangan yang belum cukup usianya untuk bisa melakukan pernikahan. Dengan berbagai sebab atas pertimbangan hukum di muka persidangan.

Kedua, budaya (tradisi). Dari segi budaya atau tradisi yang masih melekat dibeberapa masyarakat di daerah Indonesia dan sebagian menganggap bahwa perkawinan di bawah umur merupakan tindakan yang biasa. Di luar Jakarta khususnya yang biasanya mempunyai adat atau kebiasaan yang masih melekat dimasyarakat, tidak ada larangan nikah di bawah umur karena adanya kepercayaan bahwa "seorang anak perempuan yang sudah dilamar harus diterima, kalau tidak diterima bisa berakibat si anak tidak laku (tidak dapat jodoh).

Sementara di daerah lain yang biasanya menikahkan anaknya di usia dini untuk menghindari terjadinya fitnah bagi kedua pasangan yang sedang berpacaran. Hal yang sama juga terjadi di desa atau daerah lain yang masih berwilayah di Indonesia yang adat kebiasaannya terkenal dengan pernikahan sirri (rahasia), agar tidak ada cacat dari ikatan pernikahan dikemudian hari.

Alasan yang sering timbul ketika hakim mengabulkan surat permohonan untuk menikah di usia dini dikarenakan syarat yang sesuai dengan aturan hukum Islam sudah dipenuhi, dan dalam hal ini Pengadilan Agama tidak banyak menolak permohonan nikah di bawah umur karena biasanya syarat pengajuan permohonan sudah lengkap.

Ketiga, sosial (kebiasaan). Dari segi sosial di dalam masyarakat atau kebiasaan yang sudah biasa pada satuan terkecil (keluarga) yang mendorong sikap pro atau sikap mendukung yang sudah biasa terhadap pernikahan usia dini. Lebih-lebih karena faktor rendahnya pendidikan dan tingkat minimnya perekonomian serta sikap atau pandangan masyarakat yang biasanya meremehkan masalah pergaulan bebas yang menimbulkan pernikahan dini tersebut. Dan biasanya ketidaktahuan masyarakat terhadap efek buruk yang dialami seseorang yang menikah dini baik dari kesehatan maupun psikologis, menjadi alasan bagi para pihak yang terkait, baik keluarga ataupun masyarakat sekitar. Di samping itu, paradigma atau pandangan sebagian masyarakat yang menganggap bahwa adanya sebuah pernikahan akan mengangkat persoalan atau masalah ekonomi yang dihadapi, yang pada kenyataannya adalah sebaliknya.

Keempat, hukum. Dari segi aturan hukum, dalam hal ini hukum sangat mengambil peran terhadap sebuah penyelesaian dibeberapa masalah yang timbul dalam sebuah pernikahan khususnya pada pernikahan di bawah umur. Yang apabila aturan hukum tentang batasan nikah ada dan jelas serta berjalan dengan baik maka dampak yang akan timbul yakni disetiap tahun pernikahan usia dini akan berkurang.

Akibat dari pernikahan di bawah umur muncul karena beberapa faktor yang menimbulkan pernikahan dini seperti kecenderungan pergaulan bebas yang tidak dibatasi atau dibataskan oleh keluarga atau pihak-pihak yang terkait, ataupun pengawasan yang kurang ketat dari orangorang sekitar, sehingga ketika harapan yakni para remaja yang seharusnya memiliki sikap bertanggung jawab terhadap diri sendiri dan mengikuti aturan hukum yang wajar sudah sangat jauh diperhitungkan, lebih-lebih di zaman modern seperti ini yang hubungan seks pra-nikah bahkan seks bebas ataupun nikah di bawah umur menjadi suatu wabah yang sudah sangat biasa dan dianggap wajar, dan jarang sekali 
masyarakat menganggap penting masalah ini.

\section{c. Dampak Pernikahan di Bawah Umur}

Berbagai dampak pernikahan dibawah umur dapat dikemukakan sebagai berikut :

1) Dampak terhadap hukum

Adanya pelanggaran terhadap 3 (tiga) undang-undang di negara kita yaitu: ${ }^{14}$

Pertama, Undang-Undang No. 1 tahun 1974 tentang perkawinan pasal 7 (1) Perkawinan hanya diizinkan jika pihak pria sudah mencapai umur 19 tahun dan pihak wanita sudah mencapai umur 16 tahun. Pasal 6 ayat (2) Untuk melangsungkan perkawinan seorang yang belum mencapai umur 21 tahun harus mendapat izin kedua orang tua.

Kedua, Undang-Undang No. 23 tahun 2002 tentang Perlindungan Anak Pasal 26 (1) Orang tua berkewajiban dan bertanggungjawab untuk: (a) Mengasuh, memelihara, mendidik dan melindungi anak, (b) Menumbuh kembangkan anak sesuai dengan kemampuan, bakat dan minatnya, dan (c) Mencegah terjadinya perkawinan pada usia anak-anak.

Ketiga, Undang-Undang No. 21 tahun 2007 tentang PTPPO. ${ }^{15}$ Patut digarisbawahi adanya penjualan/pemindah tanganan antara kyai dan orang tua anak yang mengharapkan imbalan tertentu dari perkawinan tersebut.

Amanat Undang-undang tersebut di atas bertujuan melindungi anak, agar

14 Selengkapnya dapat dilihat pada website:http:/ / www.wordpress.com/2010/10/15/ pernikaban-dini/ akses 17 September 2019.

${ }_{15}$ Kementrian Negara Pemberdayaan Perempuan/Deputi Perlindungan Anak, Dampak Pernikahan Dini (Perkawinan Muda), Jakarta: Paper, 2010 anak tetap memperoleh haknya untuk hidup, tumbuh dan berkembang serta terlindungi dari perbuatan kekerasan, eksploitasi dan diskriminasi.

Sungguh disayangkan apabila ada orang atau orang tua melanggar undangundang tersebut. Pemahaman tentang undang-undang tersebut harus dilakukan untuk melindungi anak dari perbuatan salah oleh orang dewasa dan orang tua.

2) Dampak Bilogis

Anak secara biologis alat-alat reproduksinya masih dalam proses menuju kematangan sehingga belum siap untuk melakukan hubungan seks dengan lawan jenisnya, apalagi jika sampai hamil kemudian melahirkan. Jika dipaksakan justru akan terjadi trauma, perobekan yang luas dan infeksi yang akan membahayakan organ reproduksinya sampai membahayakan jiwa anak. Patut dipertanyakan apakah hubungan seks yang demikian atas dasar kesetaraan dalam hak reproduksi antara isteri dan suami atau adanya kekerasan seksual dan pemaksaan (penggagahan) terhadap seorang anak.

Pernikahan pada anak perempuan berusia 9-12 tahun sangat tak lazim dan tidak pada tempatnya. "Apa alasan ia menikah? Sebaiknya jangan dulu berhubungan seks hingga anak itu matang fisik maupun psikologis". Kematangan fisik seorang anak tidak sama dengan kematangan psikologisnya sehingga meskipun anak tersebut memiliki badan bongsor dan sudah menstruasi, secara mental ia belum siap untuk berhubungan seks.

\section{3) Dampak Psikologis}

Secara psikis anak juga belum siap dan mengerti tentang hubungan seks, sehingga akan menimbulkan trauma psikis berkepanjangan dalam jiwa anak yang sulit disembuhkan. Anak akan murung dan menyesali hidupnya yang berakhir pada perkawinan yang dia sendiri tidak mengerti 
atas putusan hidupnya. Selain itu, ikatan perkawinan akan menghilangkan hak anak untuk memperoleh pendidikan (Wajib 9 tahun), hak bermain dan menikmati waktu luangnya serta hak-hak lainnya yang melekat dalam diri anak.

Banyak efek negatif dari pernikahan dini. Pada saat itu pengantinnya belum siap untuk menghadapi tanggungjawab yang harus diemban seperti orang dewasa. Padahal kalau menikah itu kedua belah pihak harus sudah cukup dewasa dan siap untuk menghadapi permasalahan-permasalan baik ekonomi, pasangan, maupun anak. Sementara itu mereka yang menikah dini umumnya belum cukup mampu menyelesaikan permasalan secara matang.

\section{4) Dampak Sosial}

Fenomena sosial ini berkaitan dengan faktor sosial budaya dalam masyarakat patriarki yang bias gender, yang menempatkan perempuan pada posisi yang rendah dan hanya dianggap pelengkap seks laki-laki saja. Kondisi ini sangat bertentangan dengan ajaran agama apapun termasuk agama Islam yang sangat menghormati perempuan (Rabmatan lil Alamin). Kondisi ini hanya akan melestarikan budaya patriarki yang bias gender yang akan melahirkan kekerasan terhadap perempuan.

5) Dampak perilaku seksual menyimpang

Adanya prilaku seksual yang menyimpang yaitu prilaku yang gemar berhubungan seks dengan anak-anak yang dikenal dengan istilah pedofilia. Perbuatan ini jelas merupakan tindakan ilegal (menggunakan seks anak), namun dikemas dengan perkawinan se-akan2 menjadi legal.

Hal ini bertentangan dengan UU.No.23 tahun 2002 tentang Perlindungan Anak khususnya pasal 81, ancamannya pidana penjara maksimum 15 tahun, minimum 3 tahun dan pidana denda maksimum 300 juta dan minimum 60 juta rupiah. ${ }^{16}$ Apabila tidak diambil tindakan hukum terhadap orang yang menggunakan seksualitas anak secara ilegal akan menyebabkan tidak ada efek jera dari pelaku bahkan akan menjadi contoh bagi yang lain.

\section{Kesimpulan}

Uraian dari penjelasan yang telah disebutkan di atas, maka dapat diambil kesimpulan bahwa tidak ada pengaturan hukum yang khusus menyangkut perkawinan anak dibawah umur. Anak dibawah umur menurut sistem hukum di Indonesia yaitu Undang-Undang Perkawinan (UUP) di Indonesia adalah anak yang berusia 19 (sembilan belas) tahun untuk pria dan wanita. Walaupun telah ditegaskan mengenai batas usia minimum diperbolehkan menikah oleh Undang-Undang, namun disisi lain diberikan pengecualian untuk itu.

Pengecualian itu disebut dengan pemberian dispensasi kawin untuk anak dibawah umur. Anak dibawah umur yang mendapat dispensasi kawin boleh melaksanakan perkawinan walaupun masih dibawah umur. Anak dibawah umur yang mendapat dispensasi kawin setelah melaksanakan perkawinan, dianggap dewasa dan dianggap cakap dalam melakukan suatu perbuatan hukum, atau ia nya tidak berada dibawah pengampuan orangtuanya lagi. [] Anak (UUPA) Pasal 81 


\section{DAFTAR PUSTAKA}

Salim, Thahir. Bahan Ajar Hukum Perdata, 2009

Kitab Undang-undang Hukum Perdata

Soedharyo Soimin, Hukum Orang dan Keluarga, Jakarta: Sinar Grafika, 1992

Undang-Undang No.1 Tahun 1974 Tentang Perkawinan

Mudzakaroh Al-Azhar, Tentang Perkawinan di Bawah Umur, Jakarta: Prima Cendikia, 1985

Khoiruddin Nasution, Hukum perkawinan I, Yogyakarta: ACAdeMIA \& TAZZAFA, 2005

Kudrat Abdillah, Maylissabet, M. Taufiq, Kontribusi Bahtsul Masail Pesantren di Madura dalam Menghadapi Perkembangan Hukum Islam Kontemporer, Jurnal Perada: Jurnal Studi Islam Kawasan Melayu, 2019.

Anggota IKAPI, Kompilasi Hukum Islam (KHI), Surabaya: KARYA ANDA, 2011

K. Wancik Saleh, Hukum Perkawinan di Indonesia, Jakarta: Ghalia Indonesia, 1976

Abdul Manan, Etika Hakim dalam Penyelenggaraan Peradilan, Jakarta: Kencana, 2007

Kementrian Negara Pemberdayaan Perempuan/Deputi Perlindungan Anak, Dampake Pernikahan Dini (Perkawinan Muda), Jakarta: 2010/ akses 17-11-2013

Noni Arni, Kuatnya Tradisi, Salah Satu Penyebab Pernikahan Dini, Makalah Sosial Budaya, tanggal 16 November 2009 